\title{
構造制御形固定砥粒研磨パッドの開発* （加工特性の向上に関する検討）
}

$\begin{array}{llllll}\text { 藤 } & \text { 努*1, 榎 } & \text { 本 俊 } \text { 之*2 }^{* 2} \\ \text { 富 永 } & \text { 茂*3, 鈴木 } & \text { 眞*3 }\end{array}$

\section{Development of a Structure-Controlled Fixed Abrasive Pad (Improvement of the Processing Properties)}

\author{
Tsutomu FUJITA, Toshiyuki ENOMOTO*4, \\ Shigeru TOMINAGA and Makoto SUZUKI \\ ${ }^{* 4}$ Graduate School of Engineering, Osaka University, \\ 2-1 Yamada-oka, Suita-shi, Osaka, 565-0871 Japan
}

\begin{abstract}
Recently, there has been strong demand for replacing the loose-abrasive machining with fixedabrasive polishing because of the large amount of the waste slurry. However, the conventional fixedabrasive polishing has the problem such as low finishing efficiency. To overcome the problem, in the previous report, a structure-controlled fixed-abrasive pad which consists of a fixed-abrasive layer and an abrasive holding layer was introduced for finishing optical glass. And then the finishing efficiency of the developed pad was higher than that of the conventional pad, but on the other hand, the factors which effects on the finishing efficiency were not clear. So, this paper deals with the effects of the pad surface condition which was considered as one of the influential factors on the processing properties. As a result, the factors which effects on the finishing efficiency was clarified. In addition, high finishing efficiency was able to be achieved by optimizing the pad surface condition.
\end{abstract}

Key Words : Polishing, Lapping, Tool, Slurry-Free Finighing, Fixed-Abrasive Pad, Polishing Pad, Ceria Abrasive, Optical Glass

\section{1. 緒言}

近年, デジタルカメラ, 携帯電話やパーソナルコン ピュータなどの需要が急増し, 光学レンズやハードデ イスクなど小型かつ高性能な精密部品が大量に製造 されるようになつた.一般にこれら精密部品の最終仕 上げ工程では, 良好な表面粗さを容易に得られる遊離 砥粒研磨加工, すなわちスラリーを用いる研磨加工が 行われることが多い.しかし大量に消費するスラリー による加エコストの増加や廃液処理による環境負荷 の増大などが大きな問題となっている.

このような問題を解決するために，遊離砥粒研磨 加工を固定砥粒研磨加工へと置き換える試み ${ }^{(1)} ゙$ 多 方面でなされている.しかし遊離砥粒研磨加工と同等

* 原稿受付 2007 年 7 月 11 日.

*1 大阪大学大学院工学研究科 (-565-0871 吹田市山田丘 2-1).

*2 正員, 大阪大学大学院工学研究科.

*3 (株) ロキテクノ( 140-0013 東京都品川区南大井 6-20-12).

E-mail : enomoto@mech.eng.osaka-u.ac.jp
の表面粗さを達成した場合でも，一般に加工能率が低 く，ほとんご実用化されていないのが現状である.

そこで筆者らは, 加工能率を高めるために砥粒供 給と砥粒保持という異なる機能を担う 2 つの層が交 互にスパイラル状に配置された固定砥粒研磨パッド を提案・開発(2)した. そして実際に光学ガラスを対象 に純水のみで加工を行った結果, スラリーを用いる研 磨加工と比べ, ふちだれが大きく改善され, より高い 加工能率のもと良好な仕上げ面粗さを得ることがで きた. 一方, コンディショニング条件により研磨パッ ドの表面状態は恋化し, 加工能率はその影響を強く受 けることがわかったが, その具体的な要因については 不明であり,さらなる加工能率の向上が困難な状況に あった. また開発したパッドを実用化するためには, 安定な加工状態を再現性よく実現することが求めら れるが, やはり未検討であった.

そこで本報では，加工能率だけでなく，加工特性 の再現性などを向上させることを目的に, パッド表面 状態が加工特性に及ぼす影響について検討を行った. 


\section{2. スパイラル構造を有する固定砥粒研磨パッド}

本開発による固定砥粒研磨パッドはセリア砥粒 (平 均粒径 $0.2 \mu \mathrm{m}$ ）を結合させた砥粒層を，アクリル系 の熱可塑性樹脂からなる繊維シート (繊維層)によっ て挟み込み,このシートを螺旋状に巻き取りながらウ レタン系の熱可塑性樹脂 (樹脂層) で接着することで 作製している.図 1 にパッド表面のSEM写真を示す.

次に開発したパッドの特徴について述べる.このパ ッドでは高い加工能率を得ることを目的として砥粒 層では砥粒を高密度化 (95 wt\%) し，結合剂樹脂に よって砥粒表面が被覆されることを抑制している.し かし砥粒層は結合剤が極めて少ないため非常に脆く, パッド磨耗が激化するという課題が生じたため,繊維 層および樹脂層を設けることによって磨耗を抑えて いる.さらに繊維層および樹脂層では放出した砥粒を 保持·滞留させる効果と工作物との摺動特性を高める という効果を発現する.そしてこれらの効果によって, 遊離砥粒研磨加工と比較して砥粒消費量を $1 / 25$ に抑 え, 加工能率を $20 \%$ 向上させることができた ${ }^{(2)}$.

ここでパッド表面状態はそれら加工特性に大きく 影響を及ぼすが,そのパッド表面は繊維層から伸びて きた繊維と表面の凹凸が混在する複雑な状態になつ ている (図 1)。このためパッド表面の状態を把握す るためには,一般的に行われるパッドの3 次元プロフ アイルの測定だけではなく,繊維長さの評価も必要と される。

\section{3. パッド表面状態が加工状態に及ぼす影響}

$3 \cdot 1$ 加工再現性の評価 前報(2)の結果より, \#170 のダイヤモンドドレッサを用いて, in-situ ドレッシン グを行いながら加工をした場合, パッド内から放出さ れた砥粒濃度により加工能率が決まり，その再現性は 高いことがわかっていた. 一方で耔のの゙イヤモンド ドレッサを用いた場合, より高い加工能率が得られた ものの評価した実験回数が少なく再現性は未検討で あったそそこで\#170 ドレッサを用いた前報の実験と 同様に水およびスラリーを供給して加工を行い, 砥粒 濃度と加工能率を比較した。

実験には Lapmaster 製の片面研磨機 LP-15F を使用 し, $\Phi 420 \mathrm{~mm}, \mathrm{t} 3 \mathrm{~mm}$ のスパイラル構造固定砥粒研 磨パッド（放射状溝 32 本）を研磨定盤に設置した。 そしてスエードパッドを用いて工作物を水貼りした ホルダとドレッサをパッド上に載せ,それぞれデッド ウェイトによって圧力を調節した.さらにノズルから 純水およびセリアスラリーを供給し,工作物およびド

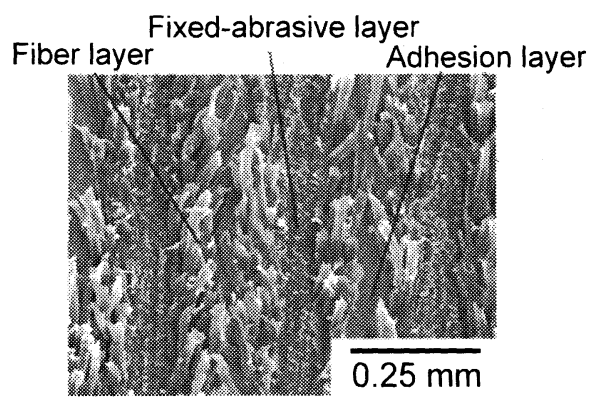

Fig. 1 SEM image of the developed pad surface

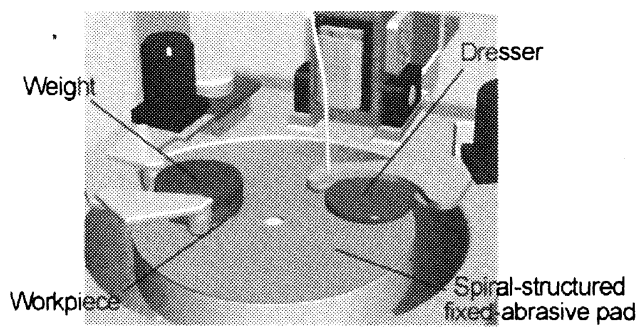

Fig. 2 Experimental set up of finishing process

Table 1 Finishing conditions

\begin{tabular}{l|l}
\hline Workpiece & $\begin{array}{l}\text { Optical glass BK7 } \\
75 \mathrm{~mm}-75 \mathrm{~mm}-\mathrm{t} 1 \mathrm{~mm}\end{array}$ \\
\hline Finishing pressure & $10,15 \mathrm{kPa}$ \\
Rotation of workpiece & $40 \mathrm{rpm}$ \\
Rotation of pad & $40 \mathrm{rpm}$ \\
Dresser & $\# 170, \# 60$ diamond dresser \\
Dressing pressure & $\# 1702.6 \mathrm{kPa}, \# 603.2 \mathrm{kPa}$ \\
Rotation of dresser & $50 \mathrm{rpm}$ \\
Finishing time & $10 \mathrm{~min}$ \\
Finishing fluid & $\cdot$ Pure water \\
& $\cdot$ Slurry with ceria abrasives \\
Supply rate & $10 \mathrm{~mL} / \mathrm{min}$ \\
\hline
\end{tabular}

レッサを回転させて加工を行った（図 2）．また加工 前には,加工中と同じドレッサを用いてパッド表面の コンディショニングを 30 分間行った. 加工条件を表 1 に示す.

砥粒濃度が加工能率に及ぼす影響を図 3 に示す.こ の結果から\#60 ドレッサを用いた場合においても，加 工能率は砥粒濃度と強い相関があり, 砥粒濃度が同等 であれば得られる加工能率はほぼ一定で, その再現性 は高いことがわかった。

ここで加工中の様子を詳細に観察したところ＃170 ドレッサを用いた場合, 工作物とパッド間の摩擦摺動 によって工作物の回転が不規則になり,テーブルの回 
転にともなって周期的な振動が生じていた. そのため に研磨中に工作物がホルダよりスリップアウトする ことがあった.これはパッド硬度が原因であると考え られ, 市販の研磨パッドと比べて本パッドは非常に硬 (2)ため, わずかな平坦度の悪化によりホルダ全体が 上下に動き, スリップアウトが発生しやすい状態にな っていた. 一方，\#60ドレッサを用いた場合，一連の 加工実験において, スリップアウトは全く生じなかっ た.

$3 \cdot 2$ 工作物スリップアウトの評価 前節から \#60 ドレッサを用いることでスリップアウトが抑制 されることを示唆する結果が得られた. そこで工作 物 - 研磨パッド間に生じる摩擦力を測定することで, 工作物のスリップアウトに強く影響を及ぼす衝撃的 な力を評価することとした.

摩擦力測定方法は以下に述べるように実際の加工 とほぼ同様の状態で行った. すなわち, 工作物として 用いているガラス板を試験片として用い, ホルダに取 り付けた. そしてホルダ全体を 2 本のアームで支え, アームとの接点にロードセルを取り付け, 試験片に加 わる摩擦力を計測した. なお, 試験片は加工とは異な り, 無回転の状態とした. ここでパッド中心に近いセ ンサを $\mathrm{CH} 1$ ，遠いセンサを $\mathrm{CH} 2$ とした（図4）。ま た測定は, 加工時と同样にパッド表面のコンディショ ニングを 30 分間行ったあとで, 摩擦力測定装置を設 置し, 10 分間評価した.

次に使用するドレッサにより変化するパッド表面 の状態を把握するために, コンディショニング後に繊 維長さと 3 次元プロファイルの評価を行った. 瀻維長 さに関しては日本電子製の走査型電子顕微鏡 JSM-5800A を用いて観察を行った. また小䛀研究所 製の 3 次元表面粗さ測定器 SE3500K 特を用いて, 3 次元プロファイルを評価した.

$3 \cdot 3$ 実験結果および考察 ドレッサによるコン ディショニング後のパッド表面の繊維長さについて 図 5 に, 3次元プロファイルについて図6に示す. ま た摩擦力については, 10 分間の評価時間では立ち上 がりの時間を除いて, ほぼ一定の值を示すことがわか った.そこで測定を始めて 1 分間後から研磨定盤がお よそ6回転する間にあたる8秒間の結果を図7に示す. 前報(2)では加工前および加工中に用いるドレッサ を変更することによって, 3 次元プロファイルが変 化することを明らかにしたが，図5からわかるよう に本開発パッドでは繊維長さも変化する. 具体的に は\#170 ドレッサを用いたときに比べ, \#60ドレッサ を用いることで繊維が長くなっているのがわかる.

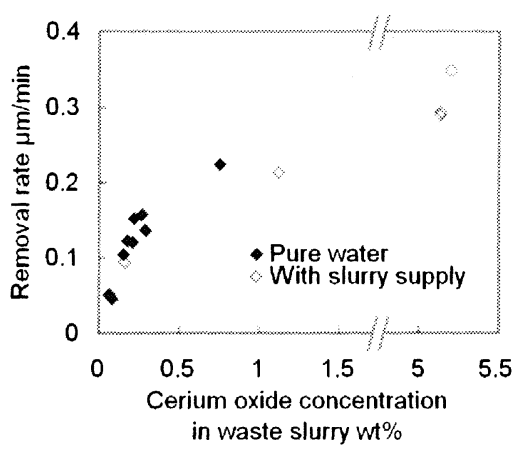

Fig.3 Relationship between material removal rate and abrasive concentration in waste slurry (usage of \#60 dresser)

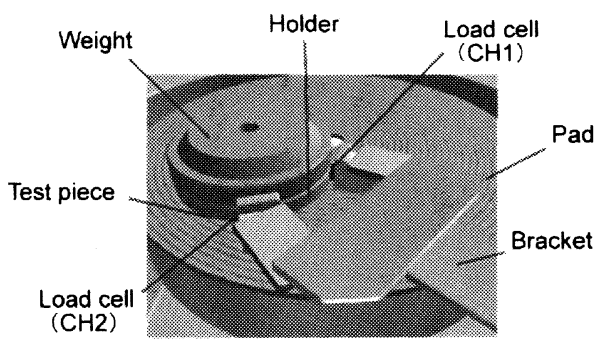

Fig.4 Schematic of the friction force measuring equipment

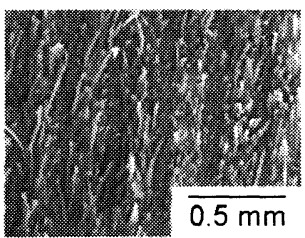

(a) Usage of \#170 dresser

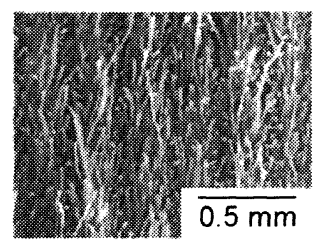

(b) Usage of \#60 dresser Fig. 5 SEM image of the pad surface

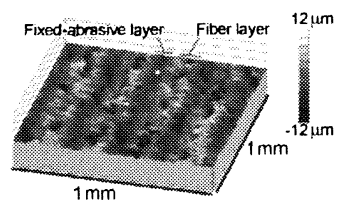

PV $41 \mu \mathrm{m}, \quad 3.4 \mu \mathrm{m} \mathrm{Ra}$ (a) Usage of \#170 dresser

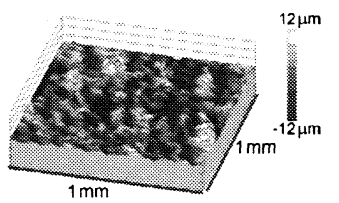

PV $67 \mu \mathrm{m}, \quad 5.8 \mu \mathrm{m} \mathrm{Ra}$ (b) Usage of \#60 dresser Fig. $63 \mathrm{D}$ profile of the pad surface

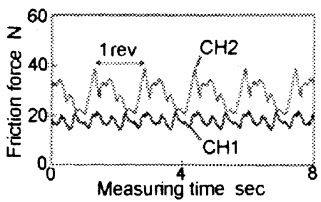

(a) Usage of \#170 dresser

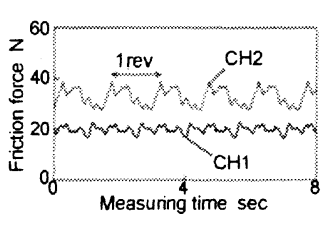

(b) Usage of \#60 dresser
Fig. 7 Friction force between the pad and the workpiece 
また図 6 から，\#170 ドレッサを用いるとパッドのス パイラル構造による凹凸が見られるが, \#60ドレッサ を用いると等方性の面になることがわかった．次に 図 7 の摩擦力測定結果から平坦度の影響を受け，工 作物に振動が発生していることが確認できた.ここ で\#170 ドレッサを用いた場合には工作物に作用す る摩擦力がテーブルの回転にともなって大きく変動 するのに対して，\#60 ドレッサを用いた場合は，そ の変動が抑えられていることがわかる，そのため工 作物に作用する摩擦力のピーク(最大摩擦力) は\#170 ドレッサとほとんど変わらないが，研磨定盤が 1 回 転する間の摩擦力の変動（摩擦力変動幅）が 60\%程 度に抑えられている。したがって衝撃的な力が緩和 されることで，工作物のスリップアウトが生じなく なったと考えられる.

$3 ・ 1$ 節で述べたように, 摩擦力変動はパッド平坦 度の影響を強く受ける. そこで\#170 と\#60の違いが 平坦度を評価するために, パッド表面の高さを測定 した (半径方向に等間隔 12 箇所, パッドの回転軸を 中心に $90^{\circ}$ ごとに行った). その結果, 平坦度は\#170 が $28 \mu \mathrm{m}, \# 60$ が $30 \mu \mathrm{m}$ となりほとんど同じである ことを確認した. したがって平坦度の違いではなく パッド表面状態の違いが工作物 - パッド間の摩擦力 変動に影響を与えたと考えられる. しかしドレッサ を変更したことにより, パッド表面状態として瀻維 長さおよび3 次元プロファイルが同時に変化してし まい，いずれが強く影響を与えるのかを特定するこ とができなかった。

\subsection{3 次元プロファイルの違いが加工状態に及ほ}

す影響 摩擦力変動に影響を与える要因を明らかに するために, パッド表面の繊維長さをそろえることで, 3 次元プロファイルのみが摩擦力変動に及ぼす影響 について検討した. 具体的にはドレッサと研磨定盤の 相対速度を高める（ドレッサ $50 \mathrm{rpm}$, 研磨定盤 50 rpm）ことで繊維長さを短いと考えられる状態に揃え， 3 次元プロファイルのみを変化させた.

こうして得られた研磨パッドの 3 次元プロファイ ルを図 8 に, 摩擦力測定結果を図 9 に示した. 図 8 から，\#170 ドレッサを用いるとパッドのスパイラル 構造による凹凸が見られ，\#60ドレッサを用いると等 方性の面になるという傾向が図 6 と同样に確認され た. 摩擦摺動特性についても図 7 と同様, \#170 と\#60 ドレッサ使用時に明らかな差違があり, \#60 ドレッサ を用いることで摩擦力変動幅を $50 \%$ 程度に抑えるこ とができた. また前節と同様に平坦度を評価したとこ ろ, \#170が $40 \mu \mathrm{m}, \# 60$ が $36 \mu \mathrm{m}$ となり大きな違い

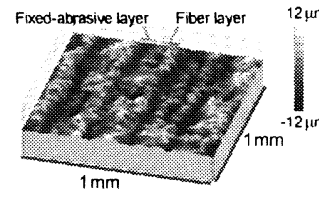

PV $50 \mu \mathrm{m}, \quad 5.9 \mu \mathrm{m} \mathrm{Ra}$ (a) Usage of $\# 170$ dresser

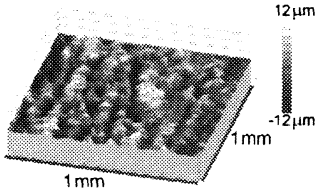

PV $48 \mu \mathrm{m}, \quad 5.4 \mu \mathrm{m} \mathrm{Ra}$ (b) Usage of \#60 dresser Fig. 8 3D profile of the pad surface

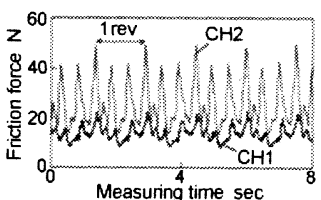

(a) Usage of \#170 dresser

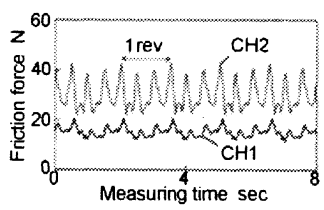

(b) Usage of \#60 dresser
Fig. 9 Friction force between the pad and the workpiece
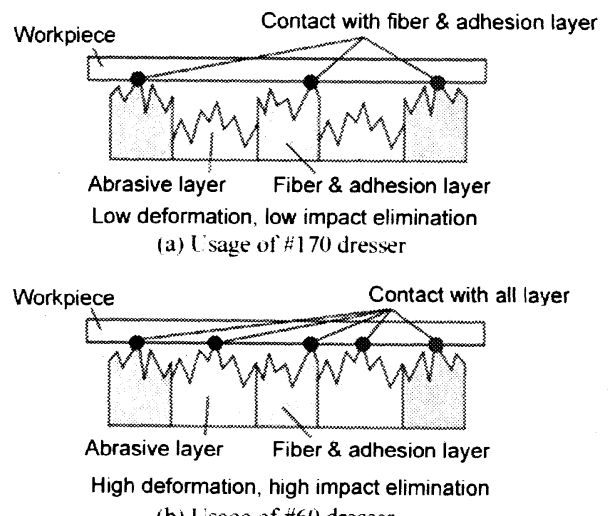
(b) Usage of $\# 60$ dresser

Fig.10 Conceptual model of influence of dresser type on pad surface condition

は無いことを確認した.これらの結果から繊維長さ が変わらない状態でも 3 次元プロファイルの違いに より摩擦力変動が抑えられており,衝撃を緩和できて いることがわかった.

この理由を明らかにするためにパッド表面の状態 を詳細に観察すると, \#170 ドレッサを用いてコンデ イショニングした場合, スパイラル構造の凹凸がみら れ，山部分の繊維・樹脂層と谷部分の砥粒層がはっき りと分かれていた. そしてこの繊維・樹脂層はくずれ にくい層であり，砥粒層は脆い層であるため, \#170 ドレッサでコンディショニングしたパッド表面は衝 撃を吸収しにくい状態であると考えられる.一方, \#60 ドレッサを用いてコンディショニングした場合, 砥粒 層と繊維·樹脂層がほぼ均等に上部にあらわれており， \#170 ドレッサによるパッド表面と比較すると衝撃を 吸収しやす状態になったと考えた (図 10)，そこで, 
このパッド表層の変形特性を調べるために, 実際にマ イクロゴム硬度計（高分子計器製 MD-1, 先端直径 $0.16 \mathrm{~mm}$ ）を用いてパッド表面の 10 点を測定した. \#170 ドレッサでコンディショニング後のパッド表面 を測定した結果, 測定 10 点中の 5 点に関して測定限 界値の 100 を超え, 平均値も 100 以上となった. 一方, \#60 ドレッサを用いたパッド表面のマイクロゴム硬 度はすべて 100 以下となり, 平均値は 97 を示した.

これらの結果から, \#170 ドレッサでコンディショ ニングしたパッド表面はスパイラル状に強固な層が あるため摩擦力変動が大きくなつたと考えられる.一 方, \#60 ドレッサによるパッド表面は脆いため, 接触 した部分がくずれることで衝撃的な力を緩和できた と考えられる.

\section{4. パッド表面状態が加工能率に及ぼす影響}

$4 \cdot 1$ 砥粒保持特性に関する検討 次に, より 高い加工能率を得ることを目的としてパッド表面状 態が加工能率に及ぼす影響について検討した. 加工能 率に影響を与える要因の一つとして,パッド表面上に 滞留する砥粒量が挙げられる. また固定砥粒研磨パッ ドにおいては,パッド内からの砥粒放出量を増大させ ることなく,パッド上での砥粒量を増やすことが求め られ,そのためパッド表面の砥粒保持特性を向上させ ることが重要である.そこでパッド表面状態の違いが 砥粒保持特性に与える影響について検討した。

砥粒保持特性は以下のように評価した.まず加工中 にパッド表面上から流れ落ちる廃液を回収した (b). そして加工終了後にパッド表面に残っている砥粒を $500 \mathrm{~mL}$ の純水で洗い流し（a），同様に回収した．そ れぞれ回収した廃液から砥粒濃度を測定し，(a) と

（b）から加工中にパッドから放出される全砥粒量

（B）を，(a）から加工後にパッド上に滞留してい た砥粒量（A）を求めた.

その結果, 砥粒保持特性を比較した場合, \#170お よび\#60 ドレッサを用いてコンディショニングした パッド表面において,大きな差がないことがわかった （表2）。しかし前章で述べたようにパッド表面の 3 次元プロファイルには明確な違いがあったために, 3 次元プロファイルは砥粒保持特性に影響を与えない ことがわかった.

\section{4・2 摺動特性の違いが加工能率に及ぼす影響} セリア砥粒によるガラスの研磨においてはガラス表 面に生成される水和軟質層が摺動により削られて加 工が進行すると考えられている. そこで工作物パッ ド間の摩擦摺動特性に着目し, 特に摩擦力に応じて除
Table 2 Comparison of the weight of the abrasive on the pad surface

\begin{tabular}{l|c|c|c}
\hline \multicolumn{1}{c|}{ Type of dresser } & $\# 170$ & $\# 60$ & $\# 55$ \\
\hline $\begin{array}{l}\text { Abrasive weight on the pad } \\
\text { after finishing (A) }\end{array}$ & $30 \mathrm{mg}$ & $28 \mathrm{mg}$ & $45 \mathrm{mg}$ \\
\hline $\begin{array}{l}\text { Total weight of the abrasive } \\
\text { (B) }\end{array}$ & $75 \mathrm{mg}$ & $72 \mathrm{mg}$ & $75 \mathrm{mg}$ \\
\hline Proportion of(A) in (B) & $40 \%$ & $39 \%$ & $60 \%$ \\
\hline
\end{tabular}

Table 3 Effect of the friction force between the pad and the workpiece on removal rate

\begin{tabular}{|c|c|c|c|c|}
\hline \multicolumn{2}{|c|}{ Type of dresser } & $\# 170$ & $\# 60$ & \#55 \\
\hline Friction force & $\mathrm{N}$ & $\begin{array}{c}45 \\
(84)\end{array}$ & $\begin{array}{c}53 \\
(100)\end{array}$ & $\begin{array}{c}49 \\
(92)\end{array}$ \\
\hline Remova & & $\begin{array}{l}0.15 \\
(85)\end{array}$ & $\begin{array}{c}0.18 \\
(100)\end{array}$ & $\begin{array}{c}0.19 \\
(106)\end{array}$ \\
\hline
\end{tabular}

The value in parenthesis indicates the relative value when setting \#60 is assumed to be 100 of the standards.

去量が大きくなると考え, 加工中の平均摩擦力 (全摩 擦力／評価時間）を評価した. その方法としては, 前 章の摩擦摺動特性を評価した実験において, 測定した 摩擦力を評価時間 10 分間にわたつて積分し, さらに 評価時間で除算することで平均の摩擦力を算出した. そして, この平均摩擦力を用いて加工能率と比較を行 った (表 3).この結果から, 加工能率と同様に平均 摩擦力が高くなっていることがわかった.

\section{5. 加工特性の向上に関する検討}

3, 4 章の結果から, パッドの表面状態によって加 工特性が大きく変化することがわかったが, 次にその 向上を目的として,工作物に発生する振動の抑制につ いてさらなる改善を試みた. そして 3 章において, 平 坦度のくずれに起因する工作物の振動を緩和するた めにはパッド表層の脆い部分を抎大することが有効 とわかった. その方法として \#60 ドレッサを用いて, パッド表面のプロファイルを変更したが, 本章では切 れ味の良いドレッサに変更し,ドレッサの押し付け圧 力を抑えてコンディショニングする方法を試みた.す なわち粒度\#55 のダイヤモンドドレッサとし, その砥 粒配列を変えることで切れ味を向上させた. 実際にコ ンディショニングを行うと $\# 60$ ドレッサの $1 / 3$ 程度の 押し付け圧力 $(1.1 \mathrm{kPa})$ で同程度の砥粒が放出される ことが確認できた（表2）。 また 3 次元プロファイル から，\#60ドレッサと同様に等方性の表面になり, 表 面粗さパラメータについては 120\%程度に抎大した （図 11）. 
以上のパッド表層の軟質化の効果を確認するため に, $3 \cdot 4$ 節と同様に摩擦変動を評価する実験を行つ た（図 12）。同図からわかるように，\#170 および\#60 ドレッサを用いた場合に対し，ほとんど変動が無く, \#170 ドレッサと比較すると約 10\%，\#60 ドレッサと 比較すると約 30\%に抑えられてことがわかった，そ して\#55 の平坦度は38 $\mu \mathrm{m}$ だうたため, \#60 と\#55を 比較して, 表面粗さパラメータについては $20 \%$ の違 い, 平坦度については 5\%の違いになっていた.これ らの違いに対し摩擦力変動幅は 70\%もの違いが表れ たため,パッド表層軟質化の効果が得られたものと推 察できる。

次に加工能率に大きな影響を与えることがわかつ た平均摩擦力について検討するために，4章と同様に 摩擦力測定と加工実験を行った（表 3）。平均摩擦力 を比較すると\#170 ドレッサよりも大きな值を示すも のの, \#60 ドレッサより若干低い値を示すことがわか った. 一方，加工能率については\#170 ドレッサ使用 時よりも高く, \#60 ドレッサを用いた場合と同程度の 加工能率が得られた.このように平均摩擦力が加工能 率に大きな影響を及ぼすという 4 章の結果と対応し ないものになった。

そこで加工能率に影響を与えると考えられる砥粒 保持特性について評価する実験を行つた．その結果， \#55 ドレッサを用いたパッド表面では他のドレッサ に比べ砥粒保持特性が大きく向上していることがわ かった（表 2）。しかし 4 章の結果からパッド表面の 3 次元プロファイルが砥粒保持特性に影響を与えな いことがわかっていた.この原因に関しては詳細は不 明ではあるが, 工作物に発生する振動が抑えられたこ とにともない最大摩擦力が大きく低減したため, 工作 物が砥粒をパッド外に押し出す力が小さくなり，砥粒 保持特性が向上したと推測できる.

以上の結果から，\#60 ドレッサと比較して \#55 ドレ ッサを用いたパッド表面では平均摩擦力が減少して いるが, 砥粒保持特性が向上したために同等の加工能 率が得られたと考えられる。

今後は, これまで詳細に検討してこなかったパッド 表面の繊維状態に着目し，それを制御することで平均 摩擦力や砥粒保持特性を高め,さらなる加工特性の向 上をはかっていく.

\section{6. 結言}

砥粒層と繊維・樹脂層からなる構造制御形固定砥 粒研磨パッドにおいて, その加工特性を高めることを

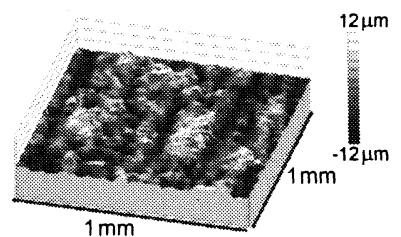

PV $59 \mu \mathrm{m}, 6.2 \mu \mathrm{m} \mathrm{Ra}$

Fig. 11 3D profile of the pad surface (usage of \#55 dresser)

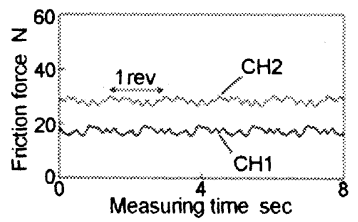

Fig. 12 Friction between the pad and the workpiece (usage of \#55 dresser)

目的に,パッド表面状態が及ぼす影響について検討を 行った結果，以下のことがわかった.

1）加工特性としてスリップアウトの原因となる衝 撃的な力の発生を評価し, パッド表層のプロファ イルを変えることで安定した加工状態を達成す ることができた.

2）低いドレス圧力（1.1 kPa）で砥粒放出量が高くな る\#55 ドレッサを用いることで，パッド表面の砥 粒保持特性を高め, 加工能率が向上し，さらに衝 撃的な力の発生を抑制できた.

本研究の一部は財団法人 日本板硝子材料工学助 成会の助成を受けて行われたことを記し,ここに深謝 申し上げます.また本研究の遂行にあたりご協力を賜 りました株式会社クリスタル光学ならびにリコー光 学株式会社に深く感謝の意を表します.

\section{文献}

(1) Sato, M.et al., Polishing of ILD and STI by the LHA Pad, Journal of the Japan Society for Precision Engineering. Vol.72, No.1(2006), pp.79-83.(in Japanese)

(2) Enomoto, T. et al., Development of the StructureControlled Fixed-abrasive Pad (Application to Finishing of an Optical Glass), Transactions of the Japan Society of Mechanical Engineers, Series C, Vol.73, No.726 (2007), pp 277-282.(in Japanese)

(3) Oliver, M.R. et al., CMP pad surface roughness and CMP removal rate, Chemical Mechanical Planarization IV,Vol.2000-26 (2001), pp. 77-83.

(4) Kim, H. et al., Pad Surface Roughness Effect on Material Removal Characteristics in Chemical Mechanical Polishing, Proceedings of Autumn Conference of the Japan Society for Precision Engineering, (2005), pp.329-330.(in Japanese) 